\title{
Imagining 'Atlanta'
}

\section{The Politics and Poetics of Space and Marginality in Medical Research in East Africa}

\section{DENIELLE ELLIOTT}

YORK UNIVERSITY, CANADA

Staff members working on AIDS prevention clinical trials in East Africa meet weekly to discuss the status of the trials and give updates on their participants. They discuss the number of new volunteers enrolled, and whether or not the weekly goals have been met; they report how many volunteers missed follow-up appointments and the number of new pregnancies, and how many volunteers seroconverted and how many withdrew from the study. These meetings usually begin with a prayer and conclude with 'AOBs'—or, 'any other business'. The chair queries each individual staff member-Apollo? Helena? Bryan?-and in response most silently shake their heads but every once in a while a team member will raise an issue that was not covered in the formal agenda. I was attending such a meeting in Kisumu, Kenya, in 2007 when one of the team members abruptly stopped the flow of the AOBs when she inquired about the possibility of buying a baby coffin for an infant enrolled in the study who had died. ${ }^{1}$

Although the child had not died as a result of the study or study procedures, a study involving parent and child, the mother had requested financial assistance from the researchers to cover costs she could not. The study coordinator, a local Kenyan 
clinician, was quick to reply. She firmly stated that the study did not cover such costs, adding that the study was responsible only for medical costs incurred while the child was alive. Upon death, the child was no longer officially enrolled in the study and thus the trial no longer had any financial obligations to the mother or family. A number of the staff members grumbled and shook their heads in disapproval, seemingly dissatisfied with the result, but the discussion was closed and AOBs continued on with the remainder of the staff. On this particular day, the principle investigator (PI) of the clinical trial, an American epidemiologist, was absent.

A few weeks later he and I were talking about his study and I recounted the story to him. In reply, or perhaps in defence, he told me another story. He was leaving work at the end of the day, driving out of the parking lot at the clinical research centre, when he noticed a woman enrolled in the trial walking home. Many trial participants travel from rural areas to participate in clinical trials in town, walking long distances and taking dangerous matatu rides to get to the city. Although participants are given a 'transport' reimbursement as part of the informed consent process, they often save it for food or other urgent expenses and instead elect to walk. ${ }^{2}$ The woman was carrying her deceased baby-the infant had died that day at Russia, the provincial hospital where research participants access medical treatment as defined by the trial protocol-and she was on her way home where, following Luo custom, the child would be buried in the family plot. The American stopped and offered to drive the woman to her rural home. He recounted that it was a long journey, an hour and half to her home along those muddy rural roads, the woman sitting silently with her dead baby. He mentioned it to one of his American colleagues the following day and he was quickly reprimanded. It was not within institutional policy and they were strictly forbidden to carry deceased individuals in a car without the proper permits. But, he asked me, 'What was I supposed to do?' His response to me-invoking a story about personal compassion and individual action-was an attempt to counter my comments on the material inequities inherent in clinical trials and global medicine. But his story also spoke subtly to the complex ways that value, ethics and spatiality merge in transnational clinical trials.

In part this article explores a theory of space and takes sites of science as its object of study, as a way to analyse the negotiation of space, power and value in 
transnational science that involve the West and East Africa. ${ }^{3}$ I want to think here about the geopolitics of science-the, sometimes improbable, spaces of experimental medicine and the connections between those spaces. Although its title is 'Atlanta', to be fair this article is not so much about a particular place, places or individuals, as it is about 'the conditions of relations' that link disparate spaces in medicine and the flows between them. ${ }^{4}$ Rajchman maps out a Deleuzian methodology to 'connections'-one that emphasises experiments, attentiveness to the unknown and unexpected, and affect. Adopting this approach, I consider a series of seemingly unrelated spaces that are connected through experimental medicine and global health in unpredictable and uncommon ways. These places-a conference venue, a freezer farm on Mercer Street, a rural shamba, a high-tech lab, a lakeside fishing village, a cargo airplane, an impassable mud road, Atlanta, Georgia, and Vancouver's inner city-tell stories about the political and economic asymmetries inherent within global medicine and the ways in which marginalities are produced and fortified in science. What follows is an experiment in writing analytically about the social relations underlining the biomateriality of global health research. My intention is to emphasise those social relations and spaces usually eclipsed in the anthropology of medical research in East Africa, with the expectation that my reader too will (re)imagine the relations between these ordinary and extraordinary spaces of science. Spaces of science connected in peculiar ways.

I begin this analytical journey at Atlanta to consider what local idioms of places might tell us about the encounters and travels of scientific artefacts and scientists in East Africa. ${ }^{5}$ How are such exclusionary spaces produced by global health research? What are the relationships between the spatial practices of medicine and postcolonial marginalities? 6 Place, in global medical research, is at once highlighted and erased. By definition 'global', place defines transnational medical research; consider the way global health departments adorn their websites and halls with photos of African children, in rural African settings. ${ }^{7}$ Erased, because in their claims of 'global' and 'universal', scientists must erase place from their scientific facts. ${ }^{8}$ John Law and Annemarie Mol have explained that our confidence in the universality of scientific facts depends 'on never asking where-questions at all'. 9 Science is constructed as placeless. In global arenas science becomes universal, and 'the view from nowhere'.10 Here, I aim to make visible the material conditions of science, 
particularly the distribution and flows between elites and subalterns, between North and South, and between the official sites and the unexpected spaces of medical research. ${ }^{11}$ In doing so, I aspire to shift the focus on medical research away from ethics to a subtler interrogation of the relations between space, marginalities and biomateriality. 12

I consider the flows of knowledge, things and peoples between these scientific spaces. ${ }^{13}$ Stacy Leigh Pigg has suggested, 'we now need to find out more about how science and technology travel, not whether they belong to one culture or another'.14 Attention to the cultural cartographies of science can help us understand the uneven configurations of power in transnational science and medicine that are often concealed by global health discourses that instead accentuate collaborations, community engagement and global epidemics. ${ }^{15}$ This is most obviously demonstrated by Dilger, Kane and Langwick's edited collection on transnational medicine in Africa. ${ }^{16}$ Their collection carefully attends to the transnational circuits in global medicine and humanitarian aid, highlighting unexpected mobilities, 'dispossessed' spaces marked by their absences, and the sometimes-productive forces of global medicine. ${ }^{17}$ I hope to contribute to this literature by focusing on the politics and poetics of unexpected social relations and the unanticipated material flows in transnational clinical trials.

President Kibaki stated in 2010 that ten million Kenyans were facing starvation. Drought, after effects of post-election violence (for instance, people still displaced, people refusing to return to their pre-election residences, on-going ethnic tensions) and poverty plague the nation even though Kenya is considered one of the better examples of stability, economic growth and peace in the region. Place plays a particularly critical role in every day social actions in Kenya-in part because place is constituent of ethnic and individual identity. ${ }^{18}$ Geneaologies of places and legends about territories are central in political discourses in Kenya. We must also consider the history of Kenya as a territory occupied-by missionaries, colonialists, and scientists, including archaeologists like the Leakeys, whose work has influenced how we imagine East Africa and whose policies shaped the lives of Kenyans through African reserves, land resettlement and the Mau Mau internment camps. 
Kisumu

Kisumu, originally Port Florence, is connected to Nairobi in the highlands and Mombasa on the coast, by the railroad built in the early 1900s by Sikh labourers, under colonial control for British East Africa, was made famous by man-eating lions. On the edge of Lake Victoria, Kisumu is a confusing montage of urban, rural, city, village, poverty, wealth. Like too many other cities today it is the site of extremes of wealth and poverty, which are also demarcated spatially_from the upscale neighborhood of Milimani, today home of the privileged (and under colonial rule the former European residential area), to the sprawling urban slum of Nyalenda, home to poor Kenyans. It is Kenya's third largest city with an estimated population of about half a million. Over half are said to live in absolute poverty. It is densely populated and most residents do not have access to clean water, indoor plumbing or electricity in their homes. The large majority of those living in the region self identify as Luo, and the area is often referred to by locals as Luoland.

Kenya, as a relatively stable nation in East Africa, has emerged as an ideal location for global health researchers from the United Kingdom, European Union and North America looking to conduct experimental medicine. ${ }^{19}$ The clinical trials that are being conducted in western Kenya are framed within a discourse of global health. In fact, the Kenya Medical Research Institute (KEMRI) renamed its Nyanza branch the Centre for Global Health Research. ${ }^{20}$ A distraction that lies embedded within this article is the problem of local/global differentiations and thus, influenced by Anna Tsing's work on 'frictions', it indirectly engages in current dialogues about the limitations of 'global' as a conceptual category and as practice. ${ }^{21}$

\section{The new international airport}

The (old) Kisumu airport is the sort of place you might expect to read about in a Michael Ondaatje poem. Under giant sycamore fig trees warm Tusker malts are served by young Kenyan men wearing starched white uniforms to those waiting for colleagues, friends and family to arrive from Nairobi. The airport has remained relatively untouched by the 9/11 events-people slide in and out unchecked past security guards. For many global health researchers, whether anthropologists, epidemiologists or medical doctors, first impressions of fieldwork in Kenya are formed at this airport. Here we exit off aging recycled planes, on to tarmac, often still steaming from the afternoon rains combined with the equatorial heat, to start or join research projects that explore malaria, HIV, and other 
tropical infectious diseases. Air travel is for the privileged in Kenya. Most Kenyans will travel to Nairobi on the Akamba bus or by matatu. The plane is reserved for the privileged, politicians and foreigners-including retired American seniors on East Africa ornithology tours in search of rare bird sightings, $\mathrm{PhD}$ students in epidemiology from Seattle, missionaries and, once in a while, Barack Obama and Bill Gates.

Kisian

The fortified research centre on the side of the lake. In 2006 President Obama visited his deceased father's home, the Kisian field research station, and participated in a Center for Disease Control (CDC) campaign to destigmatise HIV and encourage voluntary testing by being publicly tested for HIV with his wife. The Kisian field station is home to both CDC and the Kenya Medical Research Institutes' Centre for Global Health program. It is also the location of one of the most technologically advanced HIV laboratories in Africa. To enter the grounds, which are surrounded by a twelve foot cement wall topped by barbed wire, one must pass through two security gates, sign in, show photo identification, and then do it all again to enter the CDC building, but not the separate, adjacent KEMRI building. In Kisumu and neighbouring villages, local Kenyans refer to Kisian as 'Atlanta'.

What does this renaming tell us about the relationships between the research site and nation states? In part, it might be simply a reflection of the thirty-year collaboration between KEMRI and the Center for Disease Control based in Atlanta, Georgia, USA. It hints at the technoscience, the security, the privilege, the inequities and the secrecy. Perhaps it also reflects local misunderstandings of what happens there. This reinscription of place reflects anxieties and fantasies. For poor, rural Kenyans, 'Atlanta' is symbolic of privilege and technology, representing the 'American dream'. But this symbolic Atlanta in western Kenya is not the Atlanta that many Americans might imagine. Atlanta, Georgia, is a historically racialised spacerepresenting social, economic, educational and health disparities between African Americans and Euro-Americans. As a place, Atlanta (in the American south) plays a central role in the history of race relations in the United States as the home of the Atlanta race riots in 1906 and the birthplace of Martin Luther King.22 
$C D C$

But America is not at all what KEMRI senior administrators want the public to imagine when they think of this place. A senior manager reminds us that the collaboration is an agreement between two nation states, that Kenya grants permission to the $C D C$ to operate there, that employees receive pay cheques that are signed by the KEMRI director. The collective agreement between CDC and KEMRI is a complicated legalbureaucratic-economic partnership. When asked about the collaboration, a senior administrator compares the relationship to that of a parent and child, highlighting how successful children can become with good parenting. And in this case the child, CDC, 'overshadows the parent authority'. There is a social preoccupation with the CDC and the United States. Staff, research partners, local level politicians talk about 'CDC, CDC, CDC', he explains. But, he adds, 'No institute exists here called CDC. There is only KEMRI.' The buildings are 'gifts' from the US government to the Kenyan people. In 2009 they celebrated thirty years of collaboration at this site. All the past field station directors were flown in from the United Kingdom and the United States, and Kevin De Cock gave a presentation on the history of their partnership. Most KEMRI staff were not invited to the event.

Scientific spaces, whether the lab, fieldsite, airport or conference venue, are sites of performativity, sites of textual encounters, and politicised spaces. ${ }^{23}$ Fieldsites, the locations where scientists (and anthropologists) do research, are spaces of generativity where knowledge is crafted, negotiated and reshaped, and they are spaces where the local and global are reconfigured; contact zones for mobile knowledge and material artefacts, places of transactions and productivity. They are spaces of scientific authority, but also social-scientific spaces, where the routines of work are interspersed with social, personal and, sometimes, intimate encounters.

The most senior 'global' health researchers here are usually from some place else; the relationship between place and identity politics less clear, emerging as hybridised, dislocated identities. ${ }^{24}$ They are a new generation of field scientists. Some of them hold dual citizenships, have indiscernible accents, are 'missionary kids', self-identify as global citizens-and are often unable to answer the seemingly simple question 'where is home?' They are mobile citizens whose relationships to place are more likely to be shaped by their mobility than by a sense of home.25 Technological networks of information and communication also reshape their 
relationship to place. Satellite phones, cellular phones, and the internet allows global scientists to negotiate space in a way that most Kenyans cannot. ${ }^{26}$

Georgia

Senior American staff from the field centre are linked to Atlanta, Georgia, the home of the Division of HIVIAIDS Prevention, by Blackberries, satellite phones, and internet connections that connect them whereever, whenever-in the passenger seats of the white Land Cruisers as Kenyan drivers take them to rural villages to meet with local leaders, or from home late in the evenings when the eight-hour time difference with Georgia means they will be expected to sit in on late night conference calls, to debate new trial possibilties. There are shuttles that transport some staff from Kisian to town but others must take public transport. The road from 'Atlanta' to Kisumu is still full of potholes, littered with people, boda bodas, and policemen seeking bribes from matatu drivers who pick up too many passengers in their Nissan minivans or those who are driving vehicles desperately in need of repair. Brightly painted, loaded down with people, livestock and vegetables, they blare reggae or Benga music from their speakers, with Obama stickers and biblical verses plastered on their bumpers.

There is a long history of experimentation by colonial and imperial powers on the bodies of the subaltern. Although it has been suggested that the contemporary entanglements between politics and science are novel, these networks of power look eerily familiar to colonial configurations of oppression and resource (and knowledge) extraction. ${ }^{27}$ Warwick Anderson has suggested that 'global' relations are simply (post) colonial. What might be new, aside from the breadth, depth and density of the bioscientific assemblage in postcolonial Africa, are the ways in which the Kenyan state and Kenyan actors are newly complicit and entangled with these global health projects. ${ }^{28}$

\section{Kinshasa}

These relations between nation states and transnational research play out in unpredictable ways. In 2009 Dr Davy Koech, the director of KEMRI and one of its cofounders, was charged by the Kenya Anti-Corruption Commission for fraud and abuse of power. He was suspected of transferring 421 million KES, about US $\$ 5$ million, from the official KEMRI bank account to an account under his personal management-a large 
proportion of those funds were said to be CDC dollars. ${ }^{29}$ He resigned from his position taking temporary leave from his role as chief executive officer and was later suspended by the permanent secretary in the Ministry of Health. ${ }^{30}$ For two months in 2008, employees under the CDC/KEMRI agreement weren't paid their monthly wages because all accounts had been frozen by the CDC while he was being investigated for fraud. Staff members anxiously waited for salaries that in most cases they had spent or loaned long before the cheques arrived. They borrowed money from friends and from the bank, many sick with worry. Seven years later and the criminal case has not been resolved.

In 1990 at the HIVIAIDS in Africa Conference in Kinshasa Koech presented research findings that suggested orally administered interferon was effective in treating HIV. The institute claimed it was 'a miracle drug against AIDS'. ${ }^{31}$ When an American scientist in the audience, very sceptical of the findings, challenged Koech about the claims, there were counter-accusations of racism and discrimination. It resulted in a mass exodus of African researchers from the conference site. ${ }^{32}$

The province of Nyanza is a medico-administrative zone and space is rationed. ${ }^{33}$ At a private meeting, politicians, public health administrators and senior scientists divided the western part of the nation up, delineating boundaries of where particular agencies and projects would work. Medical research orients movements through spaces-research projects map, track and follow risk groups, populations, and research participants from the urban networks of town to the rural landscape. There are constant contestations between research projects over recruitment and the spaces where 'high risk' research subjects are thought to inhabit. Although projects are officially allocated particular areas for research and interventionKaremo, Bondo, Asembo or Siaya-space is still a controversial issue. As the number of trial participants required for RCTs grow, trials desperately compete for access to zones or locations where known high-risk participants may reside. Senior adminstrators try to stake claims in particular areas but these claims are tenuous. ${ }^{34}$ The borders are not stable-new players, new funds and new health priorities demand renegotiation and continual contestation over risk cartographies. Beaches (home to fishermen and fishermen's widows), small roadside towns on major highways (truck drivers and sex workers), urban slums and clinics providing antenatal care (women of reproductive age) are all desired catchment zones. Thus, particular locales take on meaning in relation to risk populations. ${ }^{35}$ In this way, 
medical research in East Africa functions as 'spatial legislation' as health programs divide up territories and thus, in part, determine rights to particular economic and social resources. 36

Clinical trials are sites of negotiation and friction where historically oppressed individuals become entangled with powerful transnational corporations (such as pharmaceutical industry, International AIDS Vaccine Initiative, the Gates Foundation) and government institutions (for example, CDC, US Army Medical Research Unit). We have entered a new phase in AIDS research. NGOs are now designing trials (like Family Health International); transnational research consortia have emerged adopting a 'venture capital approach' and advocate moving rapidly and aggressively into human testing, rather than lingering with primate trials. 'Industrial-style not-for-profit' labs are being built by NGOs that have more financial resources and international influence than some African nations. New for-profit organisations have emerged, called contract research organisations (CROs), whose main purpose is to recruit clinicians who can yield trial participants. ${ }^{37}$ This aggressive strategy is fuelled by an epidemic that many nations simply can't keep up with. In Kisumu on Thursdays and Fridays there is literally a line up of vehicles at the city morgue-people coming to collect deceased bodies to return for weekend funerals in the surrounding rural communities. Matatus carry coffins on their rooftops, and the vehicles are loaded down with family members as they head to rural Nyanza for weekend funerals with family.

\section{Russia}

In town I bicycled from one clinical trial site to another, from Lumumba to Russia to the Danish Division of Vector Borne Diseases. As I bicycle past Kenyan men walking, or waiting for boda boda passengers, I am regularly greeted with shouts of 'hey, Obamasister!' Sometimes I shout back-'I'm from Canada!' but such political or territorial distinctions mean little here where the imaginative force of America wields itself everywhere, on everyone.

The provincial hospital for Nyanza province, locally referred to as Russia but formally called the New Nyanza Provincial General Hospital, was built under colonial legislation for the local black community living in Kisumu. ${ }^{38}$ Originally built in the early 1900s, by independence (1963) it was in a bad state of disrepair. In 1965 the Kenyan 
government sought financial aid from the Russian government to repair and expand it and it was formally opened in 1969 by then President Jomo Kenyatta (resulting in ethnic demonstrations because he had imprisoned Vice President Oginga Odinga, a Luo). Russia shares the grounds today with the CDC Clinical Research Centre (CRC) and is adjacent with the US Army's Walter Reed Project, the administrative centre for US Army clinical research in western Kenya. At the Muriithi-Wellde Clinical Trial Center (CRC), a collaborative research site between the US Army Medical Research Unit (USAMRU-K) and KEMRI, for the study of malaria vaccines and pharmaceuticals, the clinical coordinator tells me that the biggest challenge at this research centre is getting blood from participants.

'The Power of Hope, the promise of research' was written across the bottom of an agenda for the grand opening of a clinical research centre in Kisumu. This framing of clinical trials and medical research-hope and promise-has no resemblance to that emerging from the work of anthropologists who have highlighted the inherent exploitative, often coercive and unethical practices of clinical trials in both the North and South. For instance, Melinda Cooper has written: 'While drug trials no longer take place within the walls of a state prison, the circumstances that drive a patient to volunteer in a clinical trial and a medical practitioner to undertake contract pharmaceutical work may be no less coercive'. ${ }^{39}$ Kaushik Sunder Rajan has argued that even if clinical trials strictly followed international ethical guidelines and laws, their very structure 'remains one of exploitation'. ${ }^{40}$ The regulatory boards and the type of ethics surrounding trials do not, as he explains, 'mitigate the fundamental structural violence of clinical trials' carried out in resource-limited settings, or, in inner-city communities of the North. ${ }^{41}$ And although they are often framed as part of a humanitarian science, pharmaceutical or biotechnical trials are entirely enmeshed with the market value that industry profits from should they be developed. Sunder Rajan maintains that medical research needs to be theorised as a 'semiautonomous sector of capital',42 but clearly both formal and informal sectors of capital. For instance, the Gates Foundation granted US\$70 million for one HIV prevention trial in East Africa; it was followed by a second prevention trial with another US $\$ 70$ million. Such immense global capital flows eclipse the muted negotiations of value in everyday scientific practice. 
In 2008 senior staff members for a clinical trial in Kisumu were puzzled by the fact that beginning around $4.00 \mathrm{am}$, people were lining up to enrol in a new study. The trial screened new participants on a 'first come, first served' basis. Given the tensions over finding and enrolling participants, trial organisers were initially thrilled by the line-up. Only when they realised that participants were paying others (who were not eligible for the trial) to wait in line with an agreement to split the 'transport fee' and that individuals were coaching each other on how to 'correctly' answer the screening questions, did the enthusiasm wane, and critical questions were raised regarding material inequities and ethics for the trial organisers. But an analysis solely of capitalist relations does not account for the history of colonialism that continues to leave its mark on these landscapes and spaces.

\section{Lumumba}

In May 2007 I arrived in Kisumu for the first time. I had only been there one week when on my way to visit a rural clinic the driver, a young Luo man, asked me what I was doing in Kenya. When I told him that I was there doing ethnographic research on HIV trials, he wanted to know if I knew anything about the UNIM trial. UNIM, a collaboration between the universities of Nairobi, Illinois and Manitoba, was one of three trial sites exploring male circumcision as an HIV prevention strategy. The driver asked me, does it work? We discussed the findings, and then he wanted to know, 'What do they do with the foreskins? Is it true that they ship them to America?' I didn't know. I wanted to say 'no, of course not' but it was possible. And in fact a few weeks later I met the PI of that trial for the first time, and I told him my story, and he confirmed that yes indeed they did ship tissue foreskin samples to Winnipeg and Chicago for analysis. Most clinical trials collect and ship blood, plasma, semen, genital mucosal secretions, saliva, breastmilk and tissue samples via a very complicated and very expensive international courier system, tracked by digital barcode labels on every sample.

Temperature, time and space coalesce. You might imagine for a moment the international, federal, state and local regulations surrounding the shipping of biological samples and infectious agents across international borders. Dry ice or liquid nitrogen, near perfect timing schedules, labelling, tracking, airport schedules, importation permits, the weather, United Nations packaging specifications, all must be carefully negotiated to ensure biological specimens arrive safely in Winnipeg, Atlanta, or Seattle. One such 
agency that specialises in the transport of biological specimens is Cryoport. Their tag line, 'transporting life', evokes science fiction imaginaries, and help us make sense of the anxieties and circulating rumours about vehicles, the United States and blood stealing in East Africa. ${ }^{43}$

There are two key differences between the trials that I am writing about here and those that have been discussed by Sunder Rajan, Cooper and Petryna. First, I am focusing on HIV prevention trials; clinical trials that are conducted on individuals who are-by the definition of the scientific protocols-healthy. ${ }^{44}$ Second, for the large part anthropologists have focused on pharmaceutical trials that are funded or entirely driven by corporate research ventures, or 'Big Pharma'. HIV/AIDS prevention trials, whether for male circumcision, microbicides, pre-exposure prophylaxis (PrEP) or vaccines, are for the most part not funded by industry but instead are funded and run by large state-like NGOs, such as Family Health International or philanthropy-based organisations like the Bill and Melinda Gates Foundation, or state-funding agencies like National Institutes for Health (NIH) in the United States, the CDC or the Canadian Institutes of Health Research.45 In April 2010 there were only two industry trials in Kisumu (both in Malaria).

While many may see the absence of industry from AIDS prevention research as auspicious, it does not account for the entanglements between industry, states, universities and the market. It suggests naïve logic where states are somehow better intentioned, or less economically motivated, than industry. ${ }^{46}$ Nor does it account for the political and economic influence that new NGOs, like the Gates Foundation or Family Health International, wield in the global AIDS and humanitarian industries. ${ }^{47}$ In western Kenya, an area characterised by abject poverty, medical research brings many benefits to the communities. Clinical trials help to offset local state-run dispensaries, whose shelves are empty-expired, or no, stock of antimalarials, antiretrovirals or antidiarrheals. Research inscribes itself deeply onto the social lives and local landscapes in western Kenya. Importantly, it offers employment in all kinds of sectors-drivers, pharmacists, nurses, medical doctors, medical anthropologists and landlords renting property all find value in experimental medicine. Employment should not be underestimated for its local value to communities, particularly in a nation with an unemployment rate of at least 40 per cent, but more likely nearer 70 per cent. ${ }^{48}$ Local Kenyans working on these trials are 
often supporting large networks of extended kin-called upon regularly to cover medical bills, school fees and everyday necessities. A burst of economic growth in the Kisumu region is marked by its materiality—cell phones, automobiles and new homes - products funded by the trial industry.

\section{Automobiles}

The automobile is an important material marker of the inequities in health research.

Toyota Land Cruisers and Land Rover Defenders transform the landscape. Automobiles have a particularly central role in rumours about medical research, blood, AIDS and foreigners. In a community where the average daily wage is 300KES (about \$US3.95), a new Land Rover valued at approximately $\$$ US50 000, becomes a sign of extreme wealth, and a reminder of extreme poverty. $C D C$ vehicles with their red embassy plates in particular are imbued with symbolic meaning—red licence plates signal the theft of blood by Americans, the extremes of American wealth that local villagers demand be redistributed to their communities, or (RED) —-the sign of AIDS. ${ }^{49}$ When I asked a former country director for CDC about the funds allocated to transport, specifically the Land Cruisers, he told me a funny story how a journalist had published a photograph in the national newspaper of a whole slough of agency vehicles, those driven by CDC, GAP, WHO, the UN, outside a brothel in Tanzania.

A Kenyan researcher tells me another story-the CDC/KEMRI vehicles carry staff to the rural villages to collect data as part of their demographic surveys or for follow-ups, going from one home to another, driving only the CDC/KEMRI staff. At the end of the day, they are returning to town and pass, walking on the side of the road, a pregnant woman in labour, a woman they have interviewed earlier in the day. The woman and her family wave for the car to stop, begging for a ride to the nearest clinic for her to deliver. The staff sitting in the vehicle tell the villagers that institutional regulations forbid them from picking up non-staff members. They drive off, leaving the woman to walk miles, in labour, risking maternal and infant life.

But automobiles do have a role in clinical trials. They pick up participants, return them, and ideally drive staff as they seek out research subjects. But the politics of the big white SUV, and its affiliation with the CDC, blood and AIDS, combined with economic constraints on fuel spending, means that too often staff must walk, take bicycles, matatus or tuk-tuks as they make their way across the urban and rural landscapes in search of 
increasingly elusive research subjects. They travel for hours on end on dirt roads, rural paths and dangerous highways looking for the ideal 'high-risk' research subject to recruit. ${ }^{50}$ Or seeking those 'habitual defaulters' who have given incorrect information for tracking so that the follow-up staff must go from marital home to rural home to maternal home, crossing through new territories and through rivers. Female staff members traverse these unfamiliar lands to be chased away with pangas and stones by village folks not accustomed to new faces, or to be assaulted on empty roads by the very men whom they have paid for a lift to those remote and rural locations.

The rates of HIV infection, combined with a long history of other tropical infectious diseases like malaria, schistosomiasis and sleeping sickness mean there is a wellestablished history of medical research in Kenya. The Kenya Medical Research Institute collaborates with a whole range of international partners, including state institutions like the CDC and the US Army Research Unit and universities from the European Union and across North America. As a result, there is a large, well-funded KEMRI field research station (Kisian), in addition to a series of smaller research centres located in Kisumu (CRC, WRP and Lumumba) has been transformed. These research centres are indicative of the ways in which scientific research carried out in Kenya. The World Health Organisation recommends that capacity building in the global South should be a priority as a means to carry out AIDS trials ethically. ${ }^{51}$ This is a move away from what one research participant called 'safari science'-when researchers fly in for a few weeks to collect data, then depart when the collection is complete. These new bioscientific projects create the necessary fields for scientific activities and these sites become the base from which all other activities are developed and ordered.

\section{Fred Hutchinson Cancer Research Centre}

For one HIV prevention clinical trial in Kenya, they expected to have a repository of one million biological specimens. For a second trial, another one million biological samples. ${ }^{52}$ Freezer farms are large warehouses that contain a range, in some cases thousands, of high-end, biomedical laboratory freezers and incubators that store biological specimens. Such freezers have ultra-low temperatures, for instance to minus 86 degrees celcius, and alarms that signal when the temperatures are not stable. The Fred Hutchinson Cancer Research Centre in Seattle is one such facility, storing millions of biological specimens 
collected from East Africans for global health researchers at the University of Washington. Although there have been efforts to build infrastructure capacity in dense clinical research settings like Kenya, most research projects still send the majority of specimens back to the principle applicant's institution for storage and analysis. Biological specimens may or may not be analysed in Kenya-depending on the particular trial. But in all cases, vasts amount of biological specimens are transported across the Atlantic Ocean to US and Canadian laboratories where they are analysed and stored in these freezer farms.

\section{Vancouver}

At a public meeting on 4 December 2005 about sixty people came together to discuss their growing concerns about the possible implementation of the Merck and Co. vaccine trial in Vancouver. Organised as part of the 6 December memorial activities for the Montreal Massacre at the École Polytechnique, a public meeting was held at the Vancouver Library, drawing media, academics, inner-city residents and feminist community advocates. During the heated and politically charged discussion, advocates raised concerns that the AIDS vaccine trials were a form of 'racialised harvesting' where impoverished, street-involved, young Aboriginal women would become the experimental subjects of a corporate drug company. In response to criticisms that the trials were taking advantage of the most 'vulnerable' women in the community, the local principle investigator responded by asking-'Well, would you rather have these drugs be tested instead on poor African women?'

\section{-CONCLUSION}

Sunder Rajan spoke about experimental subjects, Indian subjects whom, he theorised, were enrolled in clinical trials and medical research for the advancement of the health of Americans, who are no longer willing to enrol in trials. ${ }^{53}$ But in Vancouver, the inner-city community becomes the margins, for hopeful vaccines that will save 'Africa'. Possibly mentally ill, addicted or selling sex for food, money or housing, and definitely poor, these women are disposable to the Canadian state. Science reconfigures the relations between these spaces; reinforcing marginality, erasing the quotidian practices of subaltern peoples in science making, even as a new global health research discourse flaunts itself as collaborative, inclusive and 
locally appropriate. These marginal spaces, the inner city of Vancouver, Canada, and the rural shambas of western Kenya, are drawn into awkward, partial encounters by experimental medicine. Neither are post colonial in their relations to science or to each other. Although contemporary scholarship in anthropology rarely theorises inner cities of the North as connected in their post/coloniality, these sites are equally shoved into the spectre of 'global' medicine as spaces of material extraction. ${ }^{54}$ There is little evidence to suggest transnational clinical trials address inequalities in health. Rather, what the clinical trial seems to do best is to govern through the management of marginalities.

We are left having to face our own complicity in these mobile and material practices since we too are engaged in the asymmetrical global medicine industry, directly as researchers and ethnographic collaborators, our research funded by former colonial and new neoliberal institutions, and indirectly as medical consumers. Sahra Gibbons and Susan Whyte recently made a public plea, that we urgently 'address and examine social inequalities and inequities in relation to biotechnology'.55 But the question remains-how, when we are complicit in those very institutions and structures? Although it is no longer about informed consent, follow-up care and undue enticement, we are still faced with a political (and moral) dilemma, whether we work in the inner city of Vancouver or the Nyalenda slumhow do we reverse these material inequities? Is the only option a personal solution - that one of us stops and drives the woman and her dead infant home? Are these individual moments of compassion the only way to reconcile the deep disparities? But how can we rely on these personal moral commitments when so many other researchers simply drive by the woman and her dead infant, obeying institutional policy?

Denielle Elliott is Assistant Professor in the Department of Social Science at York University in Toronto, Canada. 


\section{-ACKNOWLEDGEMENTS}

The research for and writing of this article was supported by a CIHR postdoctoral research fellowship and a Wenner Gren Foundation post-PhD Award-for both, I am most grateful. I am also grateful for the professional and personal hospitality of many in the communities where this work was conducted-particularly to the scientists and staff who opened their work places and homes to me. I owe particular thanks to Philister Adhiambo for helping me navigate new landscapes, Timothy Thomas for his insights and lessons on humanitarianism and medicine in East Africa and Dara Culhane for mentoring my work on biomedicine, social suffering and an anthropology of morality. Cristina Moretti, Stacy Leigh Pigg, Crystal Biruk and Matthew Wolf-Meyer also provided very helpful comments on earlier drafts of this article. I'd lastly like to thank colleagues at the University of Maseno, Kenyawhere I presented a version of this article in March 2011-for their insightful and critical discussion of the paper and its themes.

\section{-NOTES}

1 This article is drawn from postdoctoral ethnographic fieldwork that I have been carrying out in Kenya on an assortment of clinical trials with pharmaceutical interventions for HIV/AIDS prevention. I spent eighteen months between 2007 and 2010 in East Africa carrying out observation within clinical trials and conducting interviews with staff, researchers, community members and international scientists working in East Africa. I observed recruitment strategies, tracing and follow-up practices, pharmacy support, regulatory and ethics practices, staff training, staff retreats, community advisory board meetings and the everyday administrative practices of running large-scale, multi-sited trials. I also spent time at the coordinating centre in the United States for one of the trials-at their biological storage facility, their administrative offices and at staff training seminars. Lastly, I treated scientific conferences, where the results of these trials are presented and debated, as another site of ethnographic exploration. I combine here a range of materials that have been collected from public sources; for instance, community events or meetings, scientific lectures or conferences, news publications and recordings, grey documents and email list-serves (electronic mailing lists), with private, and thus anonymised, materials from participant observation and interviews.

2 Although called a 'transport reimbursement' formally under the KEMRI IRB process, in everyday practice it is quite clearly an honorarium - a monetary incentive that both encourages individuals to participate and acknowledges the time they have given and their contribution to the study. See Wenzel Geissler, 'Transport to Where'. Journal of Cultural Economy, vol. 4, no. 1, 2011, pp. 45-64.

${ }^{3}$ Deborah Heath, 'Locating Genetic Knowledge: Picturing Marfan Syndrome and Its Traveling Constituencies', Science, Technology, and Human Values, vol. 23, no. 1, 1998, pp. 71-97; Warwick Anderson, 'From Subjugated Knowledge to Conjugated Subjects: Science and Globalisation, or 
Postcolonial Studies of Science?', Postcolonial Studies, vol. 12, no. 4, 2009:

doi:10.1080/13688790903350641; Nancy Jacobs, “The Intimate Politics of Ornithology in Colonial Africa', Comparative Studies in Society and History, vol. 48, no. 3, 2006, p. 564; Edward Said, The Word, the Text, and the Critic, Harvard University Press, Cambridge, 1983.

${ }^{4}$ Kathleen Stewart, Ordinary Affects, Duke University Press, Durham, 2007; John Rajchman, The Deleuze Connections, MIT Press, Cambridge, MA, 2000. The article is influenced by Kathleen Stewart's 'experimental ethnography' in addition to the work of a number of other anthropologists who have critiqued traditional anthropological representation, and are exploring new ways of writing. See Juan Obarrio, 'Postshamanism (1999)', Cultural Studies Review, vol. 13, no. 2, 2011: doi:postshamanism; Juan Obarrio, 'ER (...) Ellipses', Social Text, vol. 29, no. 2, 2011: doi:10.1215/01642472-1259515; Kathleen Stewart, Space on the Side of the Road, Princeton University Press, Princeton, 1996; Kathleen Stewart, 'Cultural Poesis: The Generativity of Emergent Things' in Handbook of Qualitative Research, 3rd edn, eds Norman Denzin and Yvonna Lincoln, Sage Publications, Thousand Oaks, 2005; Dara Culhane, 'Stories and Plays: Ethnography, Performance and Ethical Engagements', Anthropologica, vol. 54, 2011, pp. 257-74.

${ }^{5}$ A quick clarification on place and space: Influential geographer Tuan explains that 'what begins as undifferentiated space becomes place as we get to know it better and endow it with value' (2003: 6). Yi Fu Tuan, Space and Place: The Perspective of Experience, University of Minnesota Press, Minneapolis, 2003. Place and space require each other for definition (ibid.).

6 On a general level this article is meant to contribute to a better understanding of the relations between science and space. See Michel De Certeau, The Practice of Everyday Life, University of California Press, Berkeley, 1984; Nigel Thrift, 'Overcome by Space: Reworking Foucault,' in Space, Knowledge, and Power: Foucault and Geography, eds J. Crampton and S. Elden, Ashgate Press, Burlington, 2007; Vincanne Adams, 'The Sacred in the Scientific: Ambiguous Practices of Science in Tibetan Medicine', Cultural Anthropology, vol. 16, no. 4, 2001, pp. 542-75; Stacy Pigg and Vincanne Adams, 'Introduction: The Moral Object of Sex', in Sex in Development: Science, Sexuality, and Morality in Global Perspective, eds Vincanne Adams and Stacy Leigh Pigg, Duke University Press, Durham, 2005. In doing so, it participates in current dialogues in anthropology and geography that address the politics of space. See, for instance, Christophe Bonneuil, 'Development As Experiment: Science and State Building in Late Colonial and Postcolonial Africa', Osiris 2nd Series, no. 15, 2000, pp. 258-81; Elizabeth Guano, 'A Stroll Through La Boca', Space and Culture, vol. 6, no. 4, 2003:

doi:10.1177/1206331203257250; Beth Greenhough, 'Situated Knowledges and the Spaces of Consent', Geoforum, vol. 38, no. 6, 2007: doi:10.1016/j.geoforum.2007.02.008; Beth Greenhough, 'Tales of An Island-Laboratory: Defining the Field in Geography and Science Studies', Transactions of the Institute of British Geographers, vol. 31, no. 2, 2006, pp. 224-37; Nigel Thrift, 'Space', Theory, Culture and Society, vol. 23, no. 2-3, 2006: doi:10.1177/0263276406063780; Michael J. Watts, 'Space for Everything (A Commentary)', Cultural Anthropology, vol. 7, no. 1, 1992, pp. 115-29; Steven Shapin, 'Placing the New 
From Nowhere: Historical and Sociological Problems in the Location of Science', Transactions of the Institute of British Geographers, vol. 23, 1998, pp. 5-12; Richard Powell, 'Geographies of Science: Histories, Localities, Practices, Futures', Progress in Human Geography, vol. 31, no. 3, 2007: doi:10.1177/0309132507077081.

${ }^{7}$ Although I do not intend to explore it in this article, a similar analysis has been applied to the discipline of anthropology, and it is certainly relevant in thinking through the contemporary version of medical anthropology as advocated by some. See, for instance, Craig Janes and Kitty Corbett,

'Anthropology and Global Health', Annual Review of Anthropology, vol. 38, 2009: doi:10.1146/annurevanthro-091908-164314. As Appadurai noted, anthropology is fundamentally about places, not just in terms of the geographical spaces where we work, but because it informs anthropological knowledge. Arjun Appadurai, 'Theory in Anthropology: Center and Periphery', Comparative Studies in Society and History, vol. 28, no. 2, 1986, pp. 356-61. See also James Clifford, 'Introduction: Partial Truths' in Writing Culture: The Poetics and Politics of Ethnography, eds James Clifford and George Marcus, University of California Press, Berkeley, 1986.

8 Marc Berg and Stefan Timmermans, 'Orders and Their Others: On the Constitution of Universalities in Medical Work', Configurations, vol. 8, 2000, pp. 31-61.

9 John Law and Annemarie Mol, 'Situating Technoscience: An Inquiry Into Spatialities', Environment and Planning, Part D, Society and Space, vol. 19, 2001, p. 609. As many others have noted, spaces are inherently political; furthermore, power is spatially organised and this is similarly so in the spatial order of science. Stephen Elden and Jeremy Crampton, 'Introduction-Space, Knowledge, and Power: Foucault and Geography' in Space, Knowledge and Power: Foucault and Geography, eds Jeremy Crampton and Stephen Elden, Ashgate Press, Aldershot, 2007.

10 Steven Shapin, 'Placing the New From Nowhere: Historical and Sociological Problems in the Location of Science', Transactions of the Institute of British Geographers, vol. 23, 1998, p. 5. Geographer David Livingstone and historian of science Steven Shapin both suggest that location is essential to knowing and thus scientific knowledges are local and regional in character. See David Livingstone, 'Science, Text and Space: Thoughts on the Geography of Reading', Transactions of the Institute of British Geographers, vol. 30, no. 4, 2005, pp. 391-401. Science is inherently particular but it moves to 'global' arenas where it is presented and necessarily reordered and refashioned for the consumption of scientific and public audiences.

11 My project is thus in part a dialogue with, and yet a departure from, recent work on the political economy and biopolitics of global medicine, particularly the circulation of commodities within medicine and research. See Adams, 'The Sacred in the Scientific'; Vincanne Adams, 'Randomized Controlled Crime: Postcolonial Sciences in Alternative Medicine Research', Social Studies of Science, vol. 32, no. 5-6, 2002, pp. 659-90; Anne Anagnost, 'Strange Circulations: The Blood Economy in Rural China,' Economy and Society, vol. 35, no. 4, 2006: doi:10.1080/03085140600960781; Warwick 
Anderson, 'The Possession of Kuru: Medical Science and Biocolonial Exchange', Comparative Studies in Society and History, vol. 42, no. 4, 2000, pp. 713-44; Anderson, The Collectors of Lost Souls; Stacy Leigh Pigg, 'Languages of Sex and AIDS in Nepal: Notes on the Social Production of Commensurability', Cultural Anthropology: Journal of the Society for Cultural Anthropology, vol. 16, no. 4, 2001, pp. 481-541; Lesley Sharp, 'Commodified Kin: Death, Mourning, and Competing Claims on the Bodies of Organ Donors in the United States', American Anthropologist, vol. 103, no. 1, 2001, pp. 112-33; Lesley Sharp, 'The Commodification of the Body and its Parts', Annual Review of Anthropology, vol. 29, 2000, pp. 287328; Catherine Waldby and Robert Mitchell, Tissue Economies: Blood, Organs, and Cell Lines in Late Capitalism, Duke University Press, Durham, 2006; Kaushik Sunder Rajan, Lively Capital: Biotechnologies, Ethics and Governance in Global Markets, Duke University Press, Durham, 2012. Such attention to space and mobile practices also illuminates the ways in which states 'reinscribe and reterritorialise space' through 'transnational' scientific projects. Akhil Gupta, 'The Song of the Nonaligned World: Transnational Identities and the Reinscription of Space in Late Capitalism', Cultural Anthropology, vol. 7, no. 1, 1992), pp. 63-79.

12 There is a robust field of literature exploring the ethics of medical research in Africa. A few examples from Kenya specifically include Catherine Molyneux and Wenzel Geissler, 'Ethics and Ethnography of Medical Research in Africa', Social Science and Medicine, vol. 67, no. 5, 2008, pp. 685-95; Wenzel Geissler, “Kachinja are coming!” Encounters around Medical Research Work in a Kenyan Village', Africa, vol. 75, no. 2, 2005, pp. 173-202; and Erick Nyambedha, 'Ethical Dilemmas of Social Science Research on AIDS and Orphanhood in Western Kenya', Social Science and Medicine, vol. 67, no. 5, 2008, pp. 771-9. My aim here is to make visible a different kind of ethics, a subtler, albeit more messy, web of asymmetrical relations in transnational medical research that goes beyond questions of informed consent and monetary enticements.

13 Tsing, Frictions; Heath, 'Locating Genetic Knowledge'; Anderson, 'From Subjugated Knowledge'; Marianne De Laet and Annemarie Mol, 'The Zimbabwe Bush Pump', Social Studies of Science, vol. 30, no. 2, 2000: doi:10.1177/030631200030002002.

14 Quoted in Warwick Anderson, 'Introduction: Postcolonial Technoscience', Social Studies of Science, vol. 32, no. 5/6, 2002, p. 644 and reiterated in a personal correspondence.

15 This article offers an alternative account of the geographies of scientists and scientific things, those spaces not usually captured by researchers interested in science, space and value, and thus builds on the work of scholars such as Johanna Crane, 'Viral Cartographies: Mapping the Molecular Politics of Global HIV', Biosocieties, vol. 6, no. 2, 2011, pp. 142-66; Kean Birch, 'Knowledge, Place, and Power: Geographies of Value in Bioeconomy', New Genetics and Society, vol. 31, no. 2, 2012, pp. 183-201; Gail Davies, 'Patterning the Geographies of Organ Transplantation: Corporeality, Generosity and Justice', Transactions of the Institute of British Geographers, vol. 31, no. 3, 2006, pp. 257-71; Matthew Sparke 
and Dimitar Anguelov, 'H1N1, globalization and the epidemiology of inequality', Health and Place, vol. 18, no 4, 2012, pp. 726-36.

16 Hansjörg Dilger, Abdoulaye Kane and Stacey Langwick, Medicine, Mobility and Power in Global Africa: Transnational Health and Healing, Indiana University Press, Bloomington, 2012. But it is Warwick Anderson's historical study of the Nobel Prize winner Galdusek, Kuru and the exchange of brain matter that most influences this article, particularly his focus on the micropractices of research and commodity flows in scientific projects in colonial settings. He offers a most intimate portrait of the everyday material exchanges among medical researchers and highlights the moral complexities and contradictions involved in making science. Warwick Anderson, The Collectors of Lost Souls: Turning Kuru Scientists Into Whitemen, John Hopkins University Press, Baltimore, 2008.

17 Kristin Peterson, 'AIDS Policies for Markets and Warriors: Dispossession, Pharmaceuticals, and Capital in Nigeria' in Medicine, Mobility and Power in Global Africa: Transnational Health and Healing, Indiana University Press, Bloomington, 2012, pp. 138-59.

18 Marc Auge, An Anthropology of Contemporaneous Worlds, Stanford University Press, Stanford, 1999.

${ }^{19}$ For instance, Karen Booth documented the early HIV/AIDS research in Nairobi. It's worth noting here that many of the researchers Booth wrote about are the same characters referred to here, still working in Kenya and sometimes in Vancouver's Downtown Eastside. Karen Booth, Local Women, Global Science: Fighting AIDS in Kenya, Indiana University Press, Bloomington, 2004. Journalist Stephanie Nolen has also written a provocative piece about this phase of HIV/AIDS research in Nairobi, Kenya. Stephanie Nolen, 'Sex Slaves for Science?', The Globe and Mail, 7 January 2007, p. F4.

20 This renaming reflects institutional politics and relations. The research focus of the 'Centre for Global Health Research' is entirely local. I do not wish to focus on the theoretical problems of the global/local as concepts here but, informed by Anna Tsing and Arif Dirlik, I imagine the hybridity of global and local, and their 'indistinguishability', which forces us to account for the localisation of the global and the globalisation of the local. Dirlik writes, 'other than the most exceptional cases these phenomena are all both local and global, but they are all not local and global in the same way'. Arif Dirlik, 'Place Based Imagination: Globalism and the Politics of Place', in Places and Politics in An Age of Globalization, eds Roxann Praznial and Arif Dirlik, Rowman and Littlefield Publishers, Inc, Oxford, 2001. pp. 26-30.

21 Frederic Jameson, 'Globalization and Political Strategy', New Left Review, no. 4, no. 2, 2000, pp. 4968; Anna Tsing, 'The Global Situation', Cultural Anthropology, 2000, pp. 327-60.

22 I owe thanks to a number of colleagues at the Cascadia Conference in Seattle, WA, for pointing this out to me, particularly Stacy Leigh Pigg.

23 Thrift, 'Performance'; David Livingstone, 'Text, Talk and Testimony: Geographical Reflections on Scientific Habits. An Afterword', The British Journal for the History of Science, vol. 38, no. 1, 2005 : doi:10.1017/S000708740400648X. 
24 For instance, the WRP, CDC and GAP still employ non-Kenyans as lead investigators for many of their global health research projects, including TB, HIV, demographic surveillance and Bilharzia. There are exceptions and there is a move towards seeking out Kenyans to fill these positions. In some research programs, senior staff spoke openly about tensions in hiring practices where foreign-based (usually American) researchers were being hired rather than Kenyans, resulting in tense work environments. And, as mentioned earlier, the research being conducted at the centre focuses not on 'international health' but strictly on local, Kenyan health.

25 See Biddy Martin and Chandra Talpade Mohanty, 'Feminist Politics: What's Home Got to Do with It?' in Feminist Studies/Critical Studies, ed. Teresa de Lauretis, Indiana University Press, Bloomington, 1986. Those working for agencies such as the Walter Reed Project or the CDC are frequently relocated from one place to another every two or four years.

26 Internet access, although provided to staff in most trials, is often monitored and regulated. For instance, particular websites are blocked—such as blogs, Facebook, some email servers like Gmail, Yahoo, Hotmail and Skype-so that use is restricted.

27 Pace Rottenburg. Richard Rottenburg, 'Social and Public Experiments and New Figurations of Science and Politics in Postcolonial Africa', Postcolonial Studies, vol. 12, no. 4, 2009:

doi:10.1080/13688790903350666. Also, see Luise White, 'Cars Out of Place: Vampires, Technology, and Labor in East and Central Africa', Representations, no. 43, 1993, pp. 27-50. For instance, one might argue that the British East Africa Trade Company has been replaced by the Gates Foundation, the British Colonial government replaced by the US CDC and the US Army's Walter Reed Project, colonial and missionary scientists replaced by university-based epidemiologists and scientists, and that local agents are complicit in networks of exploitation and oppression complicated ways.

28 Anderson, 'From Subjugated Knowledges'. I owe thanks to Dara Culhane for continuously forcing me to reflect on the question 'is this new?' The Dilger, Kane and Langwick introduction also frames these relations as new but suggests they need to be situated within the historical context. A recent reading of Ruth Richardson's Death, Dissection and the Destitute has convinced me there is very little that is new about the ways in which biomaterialities are mined from resource-poor settings, whether they be in East Africa or the inner cities of the North. As she poignantly illustrates in her detailed history of anatomy, the poor have been exploited for their bodily matter since the early 1500s by medicine and the elite, long before neoliberalism, governmentality or late-capitalism. Ruth Richardson, Death, Dissection and the Destitute, University of Chicago Press, Chicago, 2001.

${ }^{29}$ Press release, Kenya Anticorruption Commission Integrity Centre, 8 January 2010.

${ }^{30}$ In 2012 the Kenyan High Court ruled in favour of allowing Koech to launch a lawsuit against KEMRI for wrongful termination.

31 Jane Perlez, 'In Kenya, a New AIDS Drug Gets Mired in Politics and Financial Disputes', New York Times, 3 October 1990. 
32 The controversy as it played out became known as the KEMRON debate.

33 Auge, An Anthropology of Contemporaneous Worlds.

${ }^{34} \mathrm{~A}$ complex set of factors influence where clinical trials are carried out. Scientists are likely to emphasise the need for running trials in areas most affected by HIV as part of the effort to develop locally relevant or culturally appropriate technologies (or, today, driven by pharmacokenetics), or because of a need for pharmaceutically naïve patients, but these offshore zones are also less expensive locations to run trials. At one particular trial I worked with, they needed to recruit over four thousand discordant couples, eight thousand individuals, across nine sites in East Africa. The investigators received US\$70 million dollars for five years, a small fraction of what such a trial would cost to run in the European Union or North America. See Steven Epstein, 'Bodily Differences and Collective Identities: The Politics of Gender and Race in Biomedical Research in the United States', Body \& Society, vol. 10, no. 2-3, 2004: doi:10.1177/1357034X04042942; Adriana Petryna, 'Ethical Variability: Drug Development and Globalising Clinical Trials', American Ethnologist, vol. 32, no. 2, 2005, pp. 183-97.

35 Van Loon has argued that epidemiology, like cultural geography, makes sense of places by spatially mapping relationships. See Joost van Loon, 'Epidemic Space', Critical Public Health, vol. 15, no. 1, 2005, pp. 39-52; Lisa Adkins, 'Risk Culture, Self-Reflexivity and the Making of Sexual Hierarchies', Body and Society, vol. 7, no. 1, 2001, pp. 35-55.

36 de Certeau, The Practice of Everyday Life.

${ }^{37}$ Adriana Petryna, When Experiments Travel: Clinical Trials and the Global Search for Human Subjects, Princeton University Press, Princeton, 2009; Robert Abadie, The Professional Guinea Pig: Big Pharma and the Risky World of Human Subjects, Duke University Press, Durham, 2010.

38 The adjacent Victoria Hospital was built for the needs of the white colonial population, with a small wing for the Asian (Indian) community.

${ }^{39}$ Melinda Cooper, Clinical Capital: Neo-Liberalism and the Will to Experiment (China and the US),

Working Paper no. 18, GBRG Working Papers, April 2007, p. 4; Melinda Cooper, 'Experimental Labour-Offshoring Clinical Trials to China', East Asian Science, Technology and Society: An International Journal, vol. 2, no. 1, 2008: doi:10.1007/s12280-008-9040-y. Jill Fisher similarly highlights the entanglements between neoliberal reform, trial contracts for medical doctors and the pharmaceutical industry in the United States. See Jill Fisher, Medical Research for Hire: The Political Economy of Pharmaceutical Clinical Trials, Rutgers University Press, New Brunswick, 2009.

40 Kaushik Sunder Rajan, 'Experimental Values: Indian Clinical Trials and Surplus Health', New Left Review, vol. 45, 2007, pp. 67-88.

41 Kaushik Sunder Rajan, 'The Experimental Machinery of Global Clinical Trials: Case Studies From India', in Asian Biotech: Ethics and Communities of Fate, eds Aihwa Ong and Nancy Chen, Duke University Press, Durham, 2010. 
42 Sunder Rajan, 'The Experimental Machinery', p. 57.

43 See White, 'Cars out of Place'; and Luise White, Speaking with Vampires: Rumour and History in Colonial Africa, University of California Press, Berkeley, 2000. But this too is not new, as Warwick Anderson provocatively highlights in his study of Kuru science in colonial New Guinea. There brain matter was commodified as a critical resource for scientists, traded among pathologists in Australia, the United Kingdom and the United States. See Anderson, The Collectors of Lost Souls. Other anthropologists who have addressed the cultural politics of 'rumours' in medicine include Amy Kaler, 'Health Interventions and the Persistence of Rumour: The Circulation of Sterility Stories in African Public Health Campaigns', Social Science and Medicine, vol. 68, 2009, pp. 1711-19; Melissa Leach and James Fairhead, Vaccine Anxieties: Global Science, Child Health and Society, Earthscan Publications, Oxford, 2007.

44 Prevention trials cannot be compared to new therapeutic trials-for instance, for someone who has end-stage AIDS, and has no other treatment options available, and thus enrols in a trial for a new, experimental drug. This is not to say that such trials are not also rife with ethical and political challenges but there are differences.

45 One exception was Merck and Co.'s Step Study—testing an experimental vaccine candidate to prevent HIV infection but the failure of this trial (not only did it not prevent infections but it appears to have increased susceptibility to HIV infection) means it is likely there will be little investment from industry in the near future.

46 Clearly this is not the case, as demonstrated by historians of medicine David Jones and Susan Reverby, among others. See Melinda Cooper, Life as Surplus, University of Washington Press, Seattle, 2008; David Jones, 'Atomic Guinea Pigs? Cold War Human Radiation Experiments', OAH Magazine of History, vol. 4, 2005, pp. 50-3; David Jones, 'The Health Care Experiments at Many Farms: The Navajo, Tuberculosis, and the Limits of Modern Medicine, 1952-1962', Bulletin of the History of Medicine, vol. 76, 2002, pp. 749-90; Susan Reverby, 'Normal Exposure' and Inoculation Syphilis: A PHS 'Tuskegee' Doctor in Guatemala, 1946-1948', Journal of Policy History, vol. 23, no. 1, 2011 : doi:10.1001/jama.2010.1554.

47 In fact, these organisations are interesting sites to consider new state formations and neoliberal forms of governance. Michel-Rolph Trouillot, "The Anthropology of the State in the Age of Globalization', Current Anthropology, vol. 42, no. 1, 2001: 125-38.

48 See <https://www.cia.gov/library/publications/the-world-factbook/geos/ke.html>.

49 For instance, the (RED) ${ }^{\mathrm{TM}}$ consumer campaign and the red ribbon campaign for AIDS. For a detailed discussion of the (RED) ${ }^{\mathrm{TM}}$ campaign, development strategies and HIV/AIDS, see Lisa Ann Richey and S. Ponte, 'Better (Red) ${ }^{\mathrm{TM}}$ Than Dead? Celebrities, Consumption and International Aid', Third World Quarterly, vol. 29, no. 4, 2008: doi:10.1080/01436590802052649. 
50 Steven Epstein has written extensively about 'recruitmentology'. See Steven Epstein, 'The Rise of "Recruitmentology": Clinical Research, Racial Knowledge, and the Politics of Inclusion and Difference', Social Studies of Science, vol. 38, no. 5, 2008: doi:10.1177/0306312708091930.

51 See <http://www.who.int/vaccine_research/capacity_strengthening/en/>; accessed 23 August 2010.

52 On line power point presentation available at <http://depts.washington.edu/deptgh/centers_institutes/icrc.php>; accessed 25 February 2011.

53 In October 2006 at the Social Studies of Science conference, Vancouver, BC.

54 I am exploring this theme, the link between these two seemingly disparate sites of marginality in more depth in another article currently in progress.

55 Sahra Gibbon and Susan Whyte, 'Introduction: Biomedical Technologies and Health Inequities for the Global North and Global South', Anthropology and Medicine, vol. 16, no. 2, 2009, p. 98. 